\title{
Warning no entry, debt restructuring in progress
}

\author{
Ankie Scott-Joseph \\ Department of Economics, The University of the West Indies, \\ Cave Hill Campus, Barbados \\ ankie.scott-joseph@,cavebill.uwi.edu
}

Abstract. Concerns about new debt restructuring episodes are on the rise as the measures necessary to combat the COVID-19 inflict harsh fiscal pressure. The decision to restructure debt is a particularly difficult one that countries should only seek as a last resort. An important question is how can a country avoid 'deceptive reputational risk' whilst attempting to reduce the cost of debt? 'To address this question, this study investigates the effect of 'deceptive reputational risk' on the outcome of debt restructuring, that is, the unintentional consequence of an increase in debt levels and the decline in gross domestic product (GDP), up to 10 years affect debt restructuring. The indicators GDP and debt-to-GDP are used to proxy 'deceptive reputational risk'. The paper utilizes Fixed Effects Panel approach to study data for Greece, Italy, Cyprus and Ireland for the period of 2000-2020. The study finds that investments, interest rate on debt and stable exchange rates can aid in minimizing 'deceptive reputational risk'. The findings are important addition to the literature on debt restructuring. To the best of the author's knowledge, this study is the first to consider reducing 'deceptive reputation risk' in fiscal policy through the use of macroeconomic variables - real effective exchange rate, interest rate on debt and investments.

Keywords: public finance, public debt sustainability, EU Member States.

JEL Classification: H62, H63

\section{INTRODUCTION}

The decision to restructure debt is a particularly difficult one that countries should only seek as a last resort. Sovereign debt restructuring mechanism imposes harsh conditions on citizens and governments of debtor states. Concerns about the sustainability of sovereign debt and new debt restructuring episodes are on the rise as the measures necessary to combat the COVID-19 outbreak have been generating expenditures that are beyond the public purse. The expectation is that there will be an increase in the average debt ratio following the Covid-19 crisis. In the Euro Area and the Caribbean, this is a critical issue 
given that the need for money creation to finance budgetary deficit has been coupled with persistent deterioration in fiscal balance. Seven countries in the euro area are expected to show debt-to-GDP ratios well above $100 \%$ in the year 2021; Greece would climb to $205 \%$, Italy to $162 \%$, Portugal to $137 \%$, France and Spain to about $120 \%$ and Belgium to $118 \%$ (IMFWEO October, 2020). These numbers are coupled with projected deteriorating fiscal balances.

A sovereign debt restructuring approach can fail in several ways: it can take too long to execute, it may not provide sufficient debt relief (Cruces \& Trebesch 2013); and, in this present study's view, it can create 'deceptive reputational risk'. A risk is simply an uncertain outcome, whereas 'deceptive reputational risk' is an outcome that triggers a false perception. In this study deceptive reputational risk refers to the danger of increased cost that countries can face in the financial market as a result of the misleading impression that increased debt levels and declining GDP can give about a country's ability to make debt payments and eventually regain sustainable levels of debt.

One quantitative indicator of 'deceptive reputational risk' in the context of debt restructuring is declining economic growth coupled with increasing debt-to-GDP, during the short and long run periods post debt restructuring. Given the contrary direction of these indicators, some countries may find it difficult to convince financial markets that their public finances are sound, particularly if they end up registering higher debt ratios than those with which they would have entered the restructuring agreements.

In more recent times three European countries restructured their debt: Ireland (2008), Greece (2012) and Cyprus (2014). Ireland's gross government debt increased to $120 \%$ of GDP by 2012 from around $42 \%$ in 2008 . There was much scepticism about the attractiveness of the country's debt restructuring agreement. Ireland's debt rescheduling arrangement involved an extension of maturities (without reduction of principal or interest). Greece 2020 debt-GDP was estimated at $217 \%$ up from $195.00 \%$ recorded in 2012. In Caribbean, five (5) territories restructured public debt recently: Jamaica (2010 \& 2013), Belize (2007, 2013 \& 2017), Grenada (2004 \& 2013), St Kitts and Nevis (2010) and Barbados (2018). These countries have all shown signs of reputational deceptive risk. In the case of Barbados public debt-GDP was an estimated $148.97 \%$, a 22.19 percentage point rise from $126.78 \%$ recorded in 2019 . Useful indicators of 'debt restructuring success' are therefore lowering public debt and increasing economic growth coupled with significant rise in foreign direct investments.

There have been several calls for debt standstills to ease the burden on countries. Three possible options are debt write-off, debt restructuring and debt roll-over. These options may have to be considered as governments may not able to contract new sovereign debt (i.e. deficit financing policy) to close fiscal deficit gap - the excess of government spending over its inflows. The best option for the debtor is to secure debt write-off, which is difficult to achieve. The second best is roll-over but this exacerbates the risk of default. Debt rescheduling is the most preferred option from the creditors' perspective. It implies debt relief, as is shifts contractual payments into the future; and is a lengthening of maturities of the old debt, possibly involving lower interest rates.

A simple workable sovereign debt RESCUE (Restore, Execute, Cancel, Utilize and Exit) plan can help countries lower debt and build market confidence. A work plan for countries must be hinged on reengineering bonds. Swapping bonds against a combination of options will be more attractive to creditors than writeoff. It is virtually impossible to convince creditors, like the IMF, to seriously consider debt forgiveness as that would mean significant asset write off. For a reprofiling programme to be effective, it must be able to programme a series of short-term bonds into longer term bonds. Government must ensure $\mathrm{CoCos}$ (i.e. contingent collateral) are written into foreign bond contracts: bonds that would automatically extend in maturity when a country receives an IMF loan. CoCos would be similar to reprofiling in effect, but different in design. Bonds should also be indexed; i.e., directly link principal and interest payments to the country's performance, particularly international reserves. While sovereign CoCos 
are meant to address liquidity crises, indexed bonds reduce the likelihood of a solvency crisis. Specifically countries should aim at:

- Restoring acceptable levels of international reserves.

- Executing necessary adjustment measures in an effort to narrow fiscal deficit balance and meet debt servicing requirements.

- Cancelling arrears and repackaging government debt to address bunching in the redemption profile. Bonds should be indexed to import cover, i.e., level of reserves. Higher reserves reduce both the likelihood of a crisis and the depth of a crisis. Maintaining adequate reserves can also boost investors' confidence and enhance investment and growth. Manipulating reserve levels can enable a country's central bank to intervene against volatile fluctuations in currency by affecting the exchange rate and increasing the demand for and value of the country's currency. Reserves act as a shock absorber against factors that can negatively affect a country's exchange rates and, therefore, the central bank uses reserves to help maintain a steady rate.

- Utilizing the private sector to close the unproductive and ineffective gaps in the public service. Governance and accountability framework should be strengthened: clearly define objectives, authorities, and accountabilities.

- Exiting debt restructuring exercise with lower debt, lower government expenditure higher revenues, restored investor confidence and regained access to capital markets. Sovereign interest rates and currency swaps could be considered.

The secret to success is good faith as 'deceptive reputational risk' tends to hamper a country's ability to restore investors' confidence. The extent of the longer-term damage to the sovereign's credit reputation may well depend on the market's perception of how the debtor country behaved during the period of its debt crisis. In this context, a few questions arise. How can a country avoid 'deceptive reputational risk' whilst attempting to reduce the cost of debt? How should countries programme debt restructuring plans to ensure they achieve success - lower debt and higher growth? The responses to these questions, as presented in this study, offer insights into the impact of 'deceptive reputational risk' on the success of debt rebalancing exercises (i.e., restructuring, rescheduling, re-profiling, roll-overs) in Europe. This study is important as it shows that among others: financial market access, investments and the real effective exchange rate are some of the key components that must be targeted to help countries to bring their debts to sustainable levels.

This paper is organized as follows: Section 2 presents the literature review; Section 3 describes the data and methodology; Section 4 discusses the findings; and, finally, Section 5 draws the conclusions

\section{LITERATURE REVIEW}

This paper is rooted in two different strands of literature. The first examines the differences between debt restructuring and debt profiling. The second, and perhaps most significant, is an explosion in the discussion on how to exit restructuring with lower debt.

\subsection{Debt restructuring and debt re-profiling}

There is a general consensus noted among the literature that reprofiling is distinct from restructuring as it seeks to shift debt service payments into the future to address liquidity concerns without imposing a significant Net present value (NPV) haircut on creditors (Gitlin \& House, 2015). Debt restructuring involves lengthening of maturities of the old debt, possibly involving lower interest rates and imply debt 
relief as they shift contractual payments into the future. Once the resolution mechanism involves/implies haircut of nominal value, debt restructuring is implied (IMF, 2012). In cases in which solvency is the known issue, debt reduction may be necessary to achieve a sustainable medium term path for the liabilities of a country. When liquidity is the issue debt rescheduling or reprofiling may be sufficient to put the country's debt on a sustainable path. An economy faces a liquidity problem when its due liabilities in a given period exceed its liquid assets. This represents a temporary cash flow problem. There is single agreed consensus on what rule can be used to help determine whether a country suffers of a solvency or liquidity.

Re-profiling mechanisms are "work and see" cases and must be done with certainty. In cases of uncertainty where neither the sustainability nor the un-sustainability of a member's debt can be established a mild instrument called "debt reprofiling' advanced by the International Monetary Fund (IMF) in 2014 can be implemented. Analysts have described reprofiling as akin to rescheduling: there is an extension of maturities on existing sovereign debt, but no change to the interest or principal (i.e. value of the debt). In the case of debt rescheduling creditors do not suffer the loss of nominal value. This implies that while maturities may be changed, there will be no overall debt reduction. A major concern is that sovereign may be forced to resort to restructuring mechanisms if a re-profiling exercise ends without success. Hence governments should strategically choose debt maturity to fill the financing across its debt redemption profile. Short-term debt has to be refinanced more frequently than longer maturity debt. Longer term debt with higher total annual issuance amounts increases governments' exposure to fluctuating funding costs and rollover risk. The maturity structure of government debt portfolio is important as it affects creditor losses in debt restructurings, long-term interest rates, exposure to fluctuating funding costs, debt sustainability levels, and consequently governments' vulnerability to crises (e.g., Kim, 2015, Beetsma et al., 2016, Asonuma et al., 2017).

Governments have a higher degree of freedom to structure the maturity profile of its outstanding debt. In 2017, Ghana reprofiled GH4.2 billion of short- and medium-term domestic debt to the longterm. In addition, an amount of about GH2.3 billion held in a Temporary Pension Fund Account, previously in 91-Day treasury bills was converted into various medium to long-term Government bonds. This did not only improve the debt profile by tenor but resulted in an interest cost savings. Governments' strategic behavior affects the choice of maturity structure. The corporate debt literature 'gapfilling' is a leading theory for analyzing strategic maturity choice (Greenwood, Hanson, and Stein GHS (2010), Badoer and James (2016), and Foley-Fisher et al. (2016)) hereafter (2010)). According to gap-filling theory, governments' debt issues would fill supply gaps across maturities, which result from varying aggregate government financing patterns. Funding costs for shorter maturities are usually cheaper than longer maturities. Nevertheless, debt with short maturity has to be refinanced more frequently; thus implying higher total annual issuance amounts which increases government's exposure to fluctuating funding costs and rollover risk.

\subsection{Lowering debt}

Countries often leave restructuring exercises with default and higher debt ratios than they would have entered with. Sovereign debt resolution methods should aid countries in increasing gross domestic product (GDP) and at the same time narrow the fiscal gap. The Greek government budget is still in an ongoing crisis (Bhimjee \& Leão, 2020). The debt to GDP ratio is above 150\%, while current fiscal deficits exceed $10 \%$. Some literature suggests that government debt has a negative effect on growth and while other concludes the relationship is positive. Baum et al. (2013), who focused on the Euro area data for the 
1990-2010 period, in a dynamic panel model, found that for those countries whose debt were sustainable there was a positive short-run impact of debt on per capita GDP growth.

A drastic increase in investments would be required by any country in crisis to allow them to change their economic and budgetary position. During crisis times open-ended investment funds, Bank deposits and treasury securities are seen as safest investments (Mentel, Brożyna \& Szetela, 2017). The relationship between the public debt and economic growth is a critical driver. Unproductive use of the government loans will impact their ability for repayment and crowds out private investments. Attard, J. (2019) supports the aforementioned viewpoints. Using data for 25 European Union members within a panel ARDL framework his empirical results establishes that debt negatively impacts economic growth both over the short- and the long-term. This negative effect is also evident across different debt levels, suggesting that the relationship between debt and growth is not influenced the initial level of debt-to-GDP ratio. Apart from highlighting the inverse relationship between debt and growth he argues that the results manifest the importance of designing policy frameworks that increase labour and human capital and encourage investment.

Government debt can foster growth by enhancing the supply of liquid assets or collateral. The empirical study of Rajan and Zingales (1998) that investigates liquidity channel of government debt found evidence of the effectiveness of liquidity. The authors utilized a sample of 28 manufacturing industries across 39 developing and developed countries, via the difference-in-differences methodology concluded that the liquidity needs tend to grow disproportionately faster in countries with higher levels of government debt in comparison to those whose debt levels were lower.

Reputational risk comprises the risk of loss in the value of a firm's value. Techniques for evaluating the reputation of the organisation vary. They include quantitative and qualitative measures such as the quality of customer service, product quality and profit levels. Each firm determines which technique it should adapt (Chun, 2005). At the country level, reputational risk is about the investors' perception. Evaluating and monitoring the change in investors' perception is therefore important. The literature identifies various parameters ranking reputation; financial soundness, long-term investment value and ability to attract, develop and retain talent. Managing reputation risks are critical for public sector; they must anticipate future needs and trends (Rayner, 2004). Existing literature does not provide a clear and comprehensive background of risk in this specific context (Brown \& Osborne, 2011).

In short, the existing literature does not provide clarity on the effectiveness of debt restructuring on growth, interest rate, exchange rates and investments. To the author's knowledge there is no literature that examines the impact of reputational risk on debt restructuring outcome. Exchange rates and interest rates are two key measures of market confidence. Changes in these variables signal countries' cost of debt and availability of credit. Creditors charge riskier countries higher interest rates. Depreciated exchange rate also signals reduction in market confidence. New and innovative approaches which investigates the usefulness polices for creating an environment to induce growth, regain investors confidence and market access and achieve the overarching objective of reducing indebtedness are useful additions to the literature.

\section{METHODOLOGY}

The study utilizes panel data models to test the hypothesis; that an increase in investments, a lowering of interest rates and an increase the growth in real effective exchange rate would lead to higher economic growth and lower public debt. The two proxies for 'deceptive reputational risk' are public GDP and debtto-GDP they are estimated in Equation 1 and 2 below. The results are displayed in Model 1 and 2, respectively. Annual data for four European countries; Italy, Greece, Cyprus and Ireland are utilized for the period 2000 to 2020 (i.e. a total of 21 annual observations per country). Investment by institutional 
sectors, Interest Government debt (nominal value) and Government deficit (net lending $(+) /$ net borrowing (-) under EDP) were migrated from EUROSTAT. These variables are all expressed as a share of GDP. The real effective exchange rate calculated as weighted averages of bilateral exchange rates adjusted by relative consumer prices were sourced from the Bank for International Settlements.

Of the four countries in the sample, Greece has the highest mean averages for public sector debtGDP $(152 \%)$, fiscal balance as a share of GDP $(-7.43 \%)$ and interest rate on debt $(5.96 \%)$ over the period 2000-2020. Ireland has the highest GDP-nominal value (207136.0) and real effective exchange rate (25.83) while Italy has the highest levels of investments as a share of GDP (98.97). See table 1. The descriptive statistics for the country group is presented in Table 2. Its shows the highest fiscal balance of about $5 \%$. Ireland would have recorded fiscal surplus during the study period.

Table 1

Descriptive statistics - country

\begin{tabular}{|l|c|c|c|c|c|c|}
\hline & & & Greece & Italy & Ireland & Cyprus \\
\hline & $\begin{array}{c}\text { Variable } \\
\text { Code }\end{array}$ & $\begin{array}{c}\text { No of } \\
\text { observations }\end{array}$ & Mean & Mean & Mean & Mean \\
\hline Debt-to-GDP & GDT & 21 & 152.35 & 115.71 & 60.6 & 112.65 \\
\hline GDP* & GDP & 21 & 189909.6 & 1573592 & 207136 & 17254.35 \\
\hline Effective Exchange Rate & EXR & 21 & 17.44 & 19.41 & 25.83 & 19.92 \\
\hline Fiscal Balance & FB & 21 & -7.44 & -3.28 & -3.8 & -4.71 \\
\hline Interest Rate & IR & 21 & 4.97 & 4.37 & 2.02 & 3.35 \\
\hline Investments & INV & 21 & 93.45 & 98.97 & 95.88 & 96.17 \\
\hline GDP Deflator & YIF & 21 & 95.55 & 92.66 & 94.52 & 94.52 \\
\hline
\end{tabular}

Source: Calculated by author in Eviews 9

Data Source: Eurostats, Bank of International Settlement and World Economic Outlook, (WEO) IMF

* expressed in euro dollars

Table 2

Descriptive Statistics - Group

\begin{tabular}{|l|c|c|c|c|c|c|c|}
\hline \multicolumn{1}{|c|}{ Group Data } & GDT & GDP & EXR & FB & IR & INV & YIF \\
\hline Mean & 110.33 & 496972.90 & 96.12 & -4.80 & 3.68 & 20.65 & 94.31 \\
\hline Median & 111.36 & 179671.70 & 96.41 & -3.61 & 3.85 & 20.73 & 98.31 \\
\hline Maximum & 217.17 & 1790942.00 & 112.58 & 4.98 & 8.12 & 45.60 & 105.02 \\
\hline Minimum & 23.42 & 10594.98 & 81.80 & -32.05 & 0.98 & 10.14 & 74.78 \\
\hline Std. Dev. & 43.66 & 635262.20 & 5.95 & 5.08 & 1.53 & 5.93 & 8.96 \\
\hline Observations & 84.00 & 84.00 & 84.00 & 84.00 & 84.00 & 84.00 & 84.00 \\
\hline
\end{tabular}

Source: Calculated by author in Eviews 9

In order to account for the persistence of the growth rate, we need a threshold model that allows for endogeneity. The study adopt the dynamic threshold methodology suggested by Kremer et al. (2009), who analyse the non-linear impact of inflation on growth within an Arellano and Bover (1995) estimation.The starting point for the threshold analysis is the specification of a linear model, which in the present case is a balanced panel of the form:

$$
y_{i t}=u_{i}+X_{i, t-1}+\alpha X_{i t}+u_{i t}
$$

$y_{i t}$ is the dependent variable, $u_{i}$ are the country specific fixed effects and $\mathrm{X}$ is a set of explanatory regressors. The error term $u_{i t}$ is independent and identically distributed with mean zero and finite 
variance. The linear model can be estimated following the Arellano and Bond (1991) dynamic panel approach. Two models are estimated; the first investigates the impact on lowering debt via GDP (Equation 2) and the second examines the impact of explanatory variables on debt (Equation 3).

The empirical specification is formulated as follows:

$$
\begin{gathered}
G D T_{i t}=u_{i}+G D T_{i, t-1}+\alpha_{I} G D P_{i t}+\alpha_{2} E X R_{i t}+\alpha_{3} R E_{i t}+\alpha_{4} F B_{i t} \\
+\alpha_{5} I N V_{i t}+\alpha_{6} Y I F_{i t}+\alpha_{7} I R_{i t}+\alpha_{8} R E S_{i t}+u_{i t} u_{i t} \\
G D P_{i t}=v_{i}+G D P_{i, t-1}+\emptyset_{I} G D T_{i t}+\emptyset_{2} E X R_{i t}+\emptyset_{3} R E_{i t}+\emptyset_{4} F B_{i t} \\
+\emptyset_{5} I N V_{i t}+\emptyset_{6} Y I F_{i t}+\emptyset_{7} I R_{i t}+\emptyset_{8} R E S_{i t}+v_{i t} v_{i t}
\end{gathered}
$$

If the model transforms into the FE model, the constant and individual effects are eliminated. If the Hausman test concludes the FE model to be the best model, this study will apply the FE robust model to validate the statistical inference. This is because the FE robust model included the robust standard errors. Thus, the FE model will be the final model used in this investigation. A dummy variable RES, was added to the model to proxy for periods of restructuring.

\section{EMPIRICAL RESULTS AND DISCUSSION}

Table 3 reports the results of the Pearson Correlation Coefficient. The tests identify highly correlated variables and allow the explanatory variables to include in the regression model. The collinearity are not greater than 0.7 . The seven explanatory variables have not collinearity or multicollinearity problem. These results give reason to proceed with empirical analysis on the interested panel data.

Table 3

Correlation

\begin{tabular}{|c|c|c|c|c|c|c|c|c|}
\hline & GDP & YIF & GDT & FB & IR & INV & EXR & RES \\
\hline GDP & 1 & & & & & & & \\
\hline YIF & -0.022 & 1 & & & & & & \\
\hline GDT & 0.071 & 0.464 & 1 & & & & & \\
\hline FB & 0.165 & -0.221 & -0.274 & 1 & & & & \\
\hline IR & 0.237 & -0.177 & 0.49 & -0.362 & 1 & & & \\
\hline INV & -0.088 & -0.261 & -0.794 & 0.168 & -0.355 & 1 & & \\
\hline EXR & 0.259 & 0.16 & -0.169 & -0.364 & 0.079 & 0.055 & 1 & \\
\hline RES & -0.097 & 0.146 & 0.176 & -0.116 & 0.071 & -0.218 & 0.026 & 1 \\
\hline
\end{tabular}

Source: Calculated by author in Eviews 9

Table 4 compares the pooled OLS and fixed-effect model; the probability value rejected the pooled mean model's null hypothesis and directed the fixed-effect model. The result of Hausman's test rejected the null hypotheses' random effect model is appropriate'. It indicates that the better model for this study is a fixed effect.

Table 4

Test statistics for model selection

\begin{tabular}{|c|c|l|}
\hline Chi Square & Probability & \multicolumn{1}{c|}{ Hypothesis } \\
\hline Hausman Specification Test 50.25 & 0.000 & Ho: Random Effect model is appropriate \\
\hline & & H1: Fixed effect model is appropriate \\
\hline
\end{tabular}

Source: Calculated by author in Eviews 9 
Table 5 reports two fixed-effect models of the same sample but replacing the main variables of explanatory variables to avoid multicollinearity problems. GDP at market prices (nominal) produces a high correlation with its categories; therefore, GDP deflator is used as an alternative proxy for GDP. Results for the two equations are presented in the framework of the Log-Level model. The second column of the table shows the dependent variable (GDP) and the second the second the dependant variable Debt-to-GDP.

The impact on debt is captured in equation (2) and the impact of restructuring on growth is examined in equation (3), and. The coefficients indicate that the interest rates, exchange rate (IR, EXR) negatively impacts economic growth, meaning that when interest rates and exchange rate increases by oneunit, the economic growth decreases $0.10 \%, 0.11 \%$, respectively.

Results for all the coefficient Investments (-25.27) and restructure dummy (-16.63) are negative and significant. They implies that for public sector debt and by extension debt restructuring possibility will decrease when the list of European countries secure investments. Therefore, higher investments lower debt. This finding is supported by Mentel, G., Brożyna, J., and Szetela, B. (2017) who argues that investment funds are important during crisis period.

Table 5

Fixed effect models

\begin{tabular}{|c|c|c|}
\hline & Model 1 & Model 2 \\
\hline Explanatory Variables & Dependant variable GDP & Dependant variable GDT \\
\hline GDP & & $-3.358(-0.340)$ \\
\hline YIF & & $56.623(2.351 *)$ \\
\hline GDT & $0.325(2.741)^{*}$ & \\
\hline$F B$ & $0.011(3.335)^{*}$ & $1.248(5.749)^{*}$ \\
\hline$I R$ & $-0.097(-2.005)^{*}$ & $1.659(5.812)$ \\
\hline$I N V$ & $0.560(2.741)^{*}$ & $-25.266(-3.135)^{*}$ \\
\hline EXR & $-0.216(0.866)$ & $-38.048(-1.837)^{*}$ \\
\hline \multirow[t]{2}{*}{ RES } & $0.113(1.722)^{*}$ & $-16.627(-3.166)^{*}$ \\
\hline & R2 0.99 DW1.33 & R2 0.97 DW 1.73 \\
\hline
\end{tabular}

Note: $\mathrm{t}$ statistics are in parenthesis significant at the $5 \%$ level

Source: Calculated by author in Eviews 9

Overall, the findings of the fixed-effect model and two robust estimators are consistent. They both act as a type of robustness check for the consistency and correct inferences of the study. The results are useful for the academics, policymakers, and private sector in external financing decisions. The findings indicates that a country can avoid 'deceptive reputational risk' whilst attempting to reduce the cost of debt, if it can simultaneously among others; secure investments, maintain favourable real effective exchange rate and contracting debt of at low interest rates during and after periods of debt restructuring.

\section{CONCLUSIONS}

The present study investigated the effect of 'deceptive reputational risk' on the outcome of debt restructuring in Greece, Ireland, Cyprus and Italy. The aim is to confirm whether investments, interest rate on debt and stable exchange rates can aid in minimizing countries' deceptive reputational risk - higher levels of debt and lower levels of growth in period after debt restructuring. The findings indicate that increases in investments and real effect exchange rates would lower a country's need to restructure public debt. It also concludes that when interest rates and exchange rate increases by one-unit, the economic growth also decreases. Therefore, governments should ensure that investments, interest rate, and 
exchange rates are efficiently and effectively programmed into restructuring plans. Such an approach would help governments to maintain investor confidence and regained access to capital markets and exit restructuring episode with lower debt and higher GDP.

\section{REFERENCES}

Achim Steiner (2018). Statement at the 37th Meeting of the International Monetary and Financial Committee. UNDP Development Programme

Arellano, C., \& Ramanarayanan, A. (2012). Default and the maturity structure in sovereign bonds. Journal of Political Economy, 120(2), 187-232,

Asonuma T., Niepelt D., \& Rancière R. (2017). Sovereign bond prices, haircuts and maturity. NBER Working Paper.

Attard, J. (2019). Public Debt and Economic Growth nexus: A Dynamic Panel ARDL approach (No. 96023). University Library of Munich, Germany.

Badoer D. C., \& James C. M. (2016). The determinants of long-term corporate debt issuances. Journal of Finance, 71(1), 457-492.

Bai Y., Kim S. T., \& Mihalache G. (2015). The maturity and payment schedule of sovereign debt. Working Paper 20896, National Burean of Economic Research.

Baum, A., Checherita-Westphal, C., \& Rother, P. (2013). Debt and growth: New evidence for the euro area. Journal of International Money and Finance 32, 809-821

Broner F. A., Lorenzoni G., \& Schmukler S. L. (2013). Why do emerging economies borrow short term?. Journal of the European Economic Association, 11:67-100, 01.

Brown, L., \& Osborne, S. (2011). Innovation in public services: engaging with risk. Public Money \& Management, 31(1).

Buera F., \& Nicolini J. P. (2004). Optimal maturity of government debt without state contingent bonds. Journal of Monetary Economics, 51(3), 531-554.

Chun. R. (2005). Corporate reputation: Meaning and measurement. International Journal of Management Reviews, 7(2), 91 109.

Cruces, J. J., \& Trebesch C. (2013). Sovereign defaults: the price of haircuts. American Economic Journal: Macroeconomics, $5(3), 85-117$.

Das, U. S., Papaioannou, M. G., Trebesch, C., \& Das, U. S. (2012). Sovereign Debt Restructurings 1950-2010: Literature Survey, Data, and Stylized Facts. IMF Working Papers, 2012(203).

Mentel, G., Brożyna, J., \& Szetela, B. (2017). Evaluation of the effectiveness of investment fund deposits in Poland in a time of crisis. Journal of International Studies, 10(2), 46-60. doi:10.14254/2071-8330.2017/10-2/3

Mukherjee, N., Zambon, S. \& Lucius, H. (2015). Do banks manage reputational risk? - a case study of European Investment Bank. Working Paper. Department of Economics and Management. University of Ferrara, Italy. https://fp7.portals.mbs.ac.uk/Portals/59/docs/KNPapers2/Do_banks_manage_Reputational_Risk.pdf

Mukhtarov, S., Yüksel, S., \& Mammadov, E. (2018). Factors that increase credit risk of Azerbaijani banks. Journal of International Studies, 11(2), 63-75. doi:10.14254/2071-8330.2018/11-2/5

Rayner, J. (2004). Managing reputational risk: Curbing tbreats, leveraging opportunities (Vol. 6). John Wiley \& Sons.

Reuter Business News (September, 2017). Ukraine's growth-linked bonds - when recovery becomes painful. Sujata Rao. LONDON (Reuters)

World Economic Outlook. (2020). Washington, D.C.: International Monetary Fund. 